\title{
Urban Biodiversity and Landscape Ecology: Patterns, Processes and Planning
}

\author{
Briony A. Norton ${ }^{1}$ - Karl L. Evans ${ }^{1}$ - Philip H. Warren ${ }^{1}$ \\ Published online: 21 November 2016 \\ (C) The Author(s) 2016. This article is published with open access at Springerlink.com
}

\begin{abstract}
Effective planning for biodiversity in cities and towns is increasingly important as urban areas and their human populations grow, both to achieve conservation goals and because ecological communities support services on which humans depend. Landscape ecology provides important frameworks for understanding and conserving urban biodiversity both within cities and considering whole cities in their regional context, and has played an important role in the development of a substantial and expanding body of knowledge about urban landscapes and communities. Characteristics of the whole city including size, overall amount of green space, age and regional context are important considerations for understanding and planning for biotic assemblages at the scale of entire cities, but have received relatively little research attention. Studies of biodiversity within cities are more abundant and show that longstanding principles regarding how patch size, configuration and composition influence biodiversity apply to urban areas as they do in other habitats. However, the fine spatial scales at which urban areas are fragmented and the altered temporal dynamics compared to non-urban areas indicate a need to apply hierarchical multi-scalar landscape ecology models to urban environments. Transferring results from landscape-scale urban biodiversity research into planning remains challenging, not least because of the requirements for urban green space to provide multiple functions. An increasing array of tools is available to meet this challenge and
\end{abstract}

This article is part of the Topical Collection on Landscape Design and Planning for Ecological Outcomes

Briony A. Norton

briony.a.norton@gmail.com

1 Department of Animal and Plant Sciences, The University of Sheffield, Western Bank, Sheffield S10 2TN, UK increasingly requires ecologists to work with planners to address biodiversity challenges. Biodiversity conservation and enhancement is just one strand in urban planning, but is increasingly important in a rapidly urbanising world.

Keywords Conservation planning · Urban ecology · Patch-matrix · Species-area relationship · Land sparing/ sharing $\cdot$ Green infrastructure

\section{Introduction}

Urban ecology is a young [1], but rapidly growing field [2]. This growing interest is associated with numerous factors, including: rapid global urbanisation [3], with most people now living, and hence experiencing nature, in urban areas [4]; predicted higher rates of urban growth in biodiversity hotspots [5], making some cities foci for threatened species conservation [6]; recognition of the impacts of urban resource use on land-use and biodiversity beyond the urban area [7, 8]; and increasing recognition of the links between biodiversity and ecosystem service provision in urban areas themselves [9]. Biodiversity is one of the key themes running through each of these issues, emphasising the importance of understanding the characteristics of urban biodiversity, the factors that drive it and how we can best design and manage urban areas to support it $[10,11]$. This endeavour must, of course, sit alongside other key environmental, social and economic agendas for urban areas [12]. Landscape ecology sits at the interface between many of these issues and plays an increasingly significant role in understanding biodiversity responses to environmental change, focusing on land-use, habitat fragmentation and scaling [13]. Against this background, and from a landscape ecology perspective, we review recent research on urban biodiversity, its conservation and its 
enhancement. Studies for the most part consider biodiversity in terms of taxonomic richness but also, to lesser extents, evenness of abundance, or the occurrence and abundance of groups of species classified by their threat status, ecological traits and functions. We start by examining whole cities in their regional context, considering how the characteristics of entire urban areas, such as city size and age, influence their biodiversity. We then consider biodiversity patterns within cities focusing particularly on the characteristics of habitat patches that are important for biodiversity, the characteristics and importance of the urban matrix for organisms and the temporal dynamics of urban green space. Here and throughout we use 'green space' to refer to any unsealed surface, regardless of its size, particularly areas with vegetation cover. We conclude by considering some of the wider issues affecting how knowledge emerging from landscape-scale urban biodiversity research is transferred into urban landscape planning and how biodiversity conservation interacts with other urban planning priorities.

\section{City-Level Biodiversity}

There is much interest in how urbanisation drives land-use change and alters biological assemblages through local species extinctions and other changes in population densities and, increasingly, such attention is focusing on these effects at the whole-city scale, i.e. how do the characteristics of entire cities affect their biodiversity? Such studies have only become possible due to the increasing availability of compilations of data on the structure and composition of biotic assemblages at the scale of entire urban areas (e.g. [14]). Analyses of such data have suggested that whilst the selection pressures associated with urbanisation do promote some level of biotic homogenisation - creation of similar communities across different urban areas [15] - there is still considerable variation in the composition of urban assemblages. For example, a number of species are not consistently urbanised throughout their range [16] and the beta diversity, i.e. spatial turnover, of urban assemblages can be considerable, even when cities are close together [17]. This variation suggests that the biodiversity found within a city may partly be determined by city-level characteristics. These characteristics can vary massively across urban areas: one such example is the amount of vegetation in cities, which varies by two orders of magnitude from less than $1 \%$ of land-cover (e.g. Kolkata) to $63 \%$ (e.g. Winnipeg) [18], with smaller, but still considerable, variation within regions, e.g. 10-36\% across 30 Chinese cities [19], and $2-46 \%$ across 386 European cities [20]. This variation in the amount of urban green space is highly likely to influence species richness [21•]. City size is another attribute that varies markedly across urban areas and that has considerable potential to influence the structure of biotic assemblages. However, urban biodiversity research is only just starting to catch up with a broader field of socio-ecological urban research that has established that city size can accurately predict numerous attributes including land-use, resource flows and economic productivity from simple power-law scaling relationships [22]. These two elements, size and green space, interact via variation in density, both of built environment, and of people: large, low density cities may be very different from smaller, high density ones. Importantly, traits such as city size and density can be influenced by the nature of planning and legislative regimes, potentially providing a means for influencing the impact of increasing urban expansion on biodiversity [23]. In this section we discuss how city context influences biodiversity, and then assess how two city-level traits, size and age, determine biodiversity patterns across cities.

\section{City Context}

The native biodiversity present in a city is inevitably a subset of the species pool in the wider surrounding area, and thus the context of a city's location can have a considerable influence on its biodiversity. Tropical cities contain more native species than temperate ones, although latitudinal species richness gradients are notably shallower across urban locations than rural ones at both global [24] and national scales [25]. Independent of this latitudinal gradient, as regional biodiversity increases, cities tend to support a decreasing proportion of the regional species pool [26•]. The reasons for this are poorly understood but it perhaps arises because tropical regions have high species richness partly because they contain a greater proportion of specialists [27], but such species rarely cope well with urban conditions ([28] and Within-city biodiversity).

The climatic zone in which a city is embedded can also influence biodiversity responses to urbanisation. Cities embedded within arid regions may have less marked reductions in biodiversity than those located in other regions [29]. In part this may arise from the habitat-matching hypothesis which suggests that locally native species cope better with urbanisation when it creates more similar habitats to a species' native habitat [16], and the open nature of urban parks and gardens is more similar to the open habitats that dominate arid regions than the dense natural vegetation that typically occurs in mesic regions. This habitat-matching hypothesis may also explain why the avifauna of tropical cities is dominated by open country rather than rainforest species [30]. Human responses to climatic zones can also determine how biodiversity responds to urbanisation. Irrigation in cities located in arid regions, for example, can promote the occurrence of some species [31], at least partly because increased water availability mitigates adverse impacts of urban heat islands [32].

Habitat quality, and other factors that determine the size of the species pool in the area surrounding a city and population sizes of its constituent species, can influence the diversity of 
species present in urban areas. Even though cities tend to support a decreasing proportion of the regional species pool as the size of that pool increases, there is an overall increase in city-level species richness as the size of the species pool increases because there are more potential colonists. Moreover, higher population sizes associated with higher quality habitats increase the potential for species to colonise urban areas through random dispersal events that lead to establishment of new viable urban populations, population spillover into urban habitats, i.e. the buffer effect, or regular supply of recruits allowing an urban sink population to be maintained. Conversely, dispersal can follow the 'good-stay, bad-disperse' rule, i.e. habitat degradation promotes greater dispersal [33]; thus, deteriorating quality of habitats surrounding urban areas may promote dispersal into towns and cities. Indeed, the goshawk (Accipter gentilis) appears to have colonised some European cities as a result of a spate of cold winters and increased (legal) hunting pressure in rural areas [34]. Whilst much more research is needed, there is evidence that the temporal population trends of birds in urban and rural areas can be tightly correlated [35], suggesting that a decline in a species' rural population does not lead to an increase in its urban population size. On balance it thus seems likely that cities surrounded by high quality environments will contain more biodiversity than similar urban areas surrounded by lower quality habitats.

\section{City Size}

Environmental conditions and associated selection pressures arising from urbanisation are frequently more intense in large cities. Large urban areas tend to have more intense urban heat islands [36], more modified precipitation regimes [37], and to be more polluted $[38,39]$ than smaller ones. In addition, larger urban areas may act as greater dispersal barriers, thus limiting the potential for dispersal or spillover of individuals from rural populations into cities. Such reductions in dispersal capacity may have important knock-on effects on other dispersal routes and ecological functionality, for example movement of rooks (Corvus frugilegus) into town centres is reduced in large cities due to travel time costs, with associated reductions in seed dispersal [40•]. Such processes suggest that in urban areas and other highly modified systems, the edges of an area comprise higher quality habitat for most species than the core areas - which is the reverse of the pattern typically seen in ecological systems [41]. Any negative effects of city size on biodiversity may be reduced in large cities if they contain a greater proportion of green space, and that greenspace increases connectivity between urban and rural populations [42]. This compensatory mechanism, however, seems rare: whilst some large cities do contain extremely large blocks of urban green space that can provide refugia for a number of taxa (e.g. New York's 3.4 km² Central Park; Madrid's 1.4 km²
El Retiro), total urban green space typically increases roughly in proportion to city size [20].

There are clearly a number of possible mechanisms through which city size could influence the number and type of species occurring in urban areas. One approach to assessing these impacts is to consider the form of speciesarea relationships [43]. Consistent and accurate data on the geographic extent of urban areas are not straightforward to obtain, in part because there is still no standard global definition of how built up a parcel of land should be before it is classified as urban, or of an appropriate spatial grain size for forming this definition. Consequently, some studies of citylevel species-area relationships use human population size as a measure of city size (e.g. [44]). However, this measure makes it difficult to separate the effects of city area and human population density, both of which may be important influences on biodiversity. The few studies that do assess how the total number of species in a city is related to its geographic extent suggest that urban assemblages do exhibit species-area relationships [45], and the slopes of these relationships appear to be similar to those in rural areas [26•]. The amount of evidence for the form of urban species-area relationships is, however, limited and megacities are particularly poorly represented in these analyses. Notably, work conducted across the UK landscape, one of the globe's most urbanised regions, concluded that the slopes of species-area relationships are lowest in areas with the highest human population density, i.e. urban areas, suggesting that cities accumulate species more slowly as their size increases than rural areas [46]. A major mechanism that contributes to the species-area relationship in rural areas is that larger areas typically contain a greater diversity of habitat types, and thus an increasing number of habitat-restricted species occur in larger areas [47]. This mechanism seems unlikely to drive species-area relationships in urban areas beyond a certain threshold of city size, as spatial patterns in habitat diversity in urban areas are extremely fine-grained (see Within-city biodiversity). The area-habitat diversity relationship thus seems likely to saturate quickly, reducing the gain in species richness as the spatial extent of cities increases, and there is empirical evidence for this [48].

Additional assessments of how biodiversity responds to city size, especially ones incorporating mega cities, are needed and these should move beyond simple descriptions of speciesarea relationships and consider assemblage composition. Considering how species' traits, if these are selected appropriately, are associated with the direction and magnitude of responses of individual species to city size will be particularly useful in assessing if responses to city size are driven by increased selection pressures or increased dispersal barriers in larger cities. Understanding the joint effects of city area and population density on biodiversity is also central to understanding the biodiversity consequences of expansive or 
compact patterns of urban growth (see Urban diversity in planning and management).

\section{City Age}

The amount of time that has elapsed since an urban area was developed, i.e. city age, can influence the number and type of species found in that city through a diverse set of mechanisms that are linked to local colonisation and extinction rates. Older urban areas have had more time for the adverse impacts of urbanisation to be realised, i.e. a greater proportion of a city's extinction debt will have already been realised, thus reducing the number of native species. Extinction debts in cities have rarely been quantified but there is evidence they can be considerable [49, 50], and larger in younger cities [51]. Conversely, in older urban areas more time has also been available for species to adjust to urban selection pressures [16], or to re-colonise vegetated areas, which is likely to be particularly important for species that require mature vegetation (due to the time required for newly planted vegetation to mature). Certainly at small spatial scales, many studies have found that local species richness increases with the age of an urban development, a pattern which is typically considered to arise as a consequence of vegetation maturation or succession and the increased time available for colonisation (e.g. [52, 53]).

Very few studies have assessed how city age influences biodiversity, perhaps in part because many cities are composed of districts that vary greatly in their age, which complicates analyses. At the level of genetic diversity, the time since urban populations became established can be positively associated with the loss of genetic diversity [54], but additional studies are required before this can be established as a general pattern. With regard to species diversity, two global analyses of native plant species generate highly conflicting evidence regarding the impacts of city age. Hahs et al. [51] find that native plant diversity declines over time, whilst Aronson et al. [21•] find that the proportion of the regional species pool of native plants retained within a city actually increases with city age. Although there are some methodological differences (e.g. Hahs et al. [51] use data from cities in which botanical surveys have been repeated in at least two different time periods, and Aronson et al. [21•] compare urban and rural species lists under the assumption that all rural species previously occurred within the city limits prior to development), the differences in the two results are difficult to reconcile. Aronson et al. [21•] also examined the pattern for birds and found that city age did not influence the proportion of the regional species pool retained within a city. The overall effect of city age on biodiversity is thus unclear but ultimately must be a balance between local extinction and colonisation events [16]. Longterm longitudinal studies within urbanised regions typically demonstrate a decline in native species richness (e.g. [55]) suggesting that, over a given unit of time, extinction debts are usually larger than colonisation debts and that city age is likely to be negatively associated with native species richness.

\section{Within-City Biodiversity}

Research into biodiversity at the level of the whole city is an emerging field that clearly highlights that city-level attributes can influence species assemblages. The distribution of biodiversity within a city and fine-scale spatial variation in the composition of urban species assemblages is, however, highly dependent on local spatial variation in factors such as land-use and land-cover within cities. Investigation of the relationships between biodiversity and internal spatial variation in cities is a field with a much longer tradition in urban landscape ecology research [56]. There is now a substantial body of empirical, landscape-scale urban ecology research that uses concepts such as urban edge-to-centre gradients [57, 58], non-linear urban gradients [59, 60], and habitat patch characteristics [61 • to advance understanding of the factors structuring urban biotic assemblages at fine spatial scales. These approaches have often applied a patch-matrix view of the landscape to understand biodiversity patterns, where the landscape is primarily viewed as patches of habitat embedded within an inhospitable matrix of non-habitat $[58,61 \cdot 62]$.

The patch-matrix concept has, in many respects, been a useful and productive approach. It has resulted in some apparently robust generalisations about biodiversity in urban environments, including that species richness is generally higher in larger patches of green space $[61 \bullet, 63,64]$ and that increasing perimeter to area ratio of patches can decrease species richness $[61 \bullet, 64]$. Results regarding connectivity are more equivocal and, although this can partly be explained by variation in species' dispersal abilities and the extent to which patches are isolated, the quality of the matrix can also play a role [61•, 65-69]. In particular, the density of urban development surrounding a patch is a frequent focus of study, and higher density development is generally associated with lower patch-level species richness, although patterns vary with taxonomic group [29, 57, 61•,63, 70-72]. Indeed, evidence is increasingly emerging that viewing urban landscapes as binary patches of hospitable habitat surrounded by an inhospitable matrix perception is too simplistic.

Limitations of the patch-matrix concept when applied to terrestrial systems have long been recognized (e.g. [73]). Two key challenges are the reliance on human perception to delimit patches, which may not be perceived as single, usable areas by other species [74-76], and the perception of the world as a binary division of habitat or inhospitable matrix - a view that is increasingly being challenged [77], both conceptually [78, 79] and empirically (e.g. [80-82]). Compared to many terrestrial systems, urban areas seem to fit a patch-matrix model well because impervious surfaces and buildings create sharp 
and seemingly inhospitable barriers. Furthermore, the framework is still widely used in planning when considering biodiversity in management and development plans (see Urban biodiversity in planning and management). The urban matrix is, however, a spatially and temporally dynamic mosaic of green and built space $[83,84]$ and there is a need to better understand this complex mosaic and how it supports biodiversity at multiple scales $\left[85,86^{\circ}\right]$, and to then translate that knowledge to inform and improve urban planning decisions.

\section{Fragmentation and the Urban Matrix}

Urban biodiversity research is broadening the perception of urban landscapes away from a focus on a simple dichotomy between habitat patches and the non-habitat matrix. This is an important move for three main reasons. First, whilst urban biodiversity research has focused disproportionately on remnant native habitat [87] and, to a lesser extent, urban parks [88], other vegetation patches, including allotments, gardens, brownfields and railway edges, can support considerable diversity across a range of taxa [89-93]. Even areas that are predominantly covered by impervious surfaces can support plants and thus provide resources for other species, for example street trees and weeds growing in pavements $[94,95]$. Second, a considerable proportion of the total amount of green space within cities is comprised of small areas of green space that are highly fragmented by impervious surfaces [96-98]. This can lead to highly complex spatial patterns of grey and green spaces [83] with fine-grained fragmentation patterns not typical of non-urban landscapes [99]. Third, urban green spaces are internally fragmented at small scales by a structurally and compositionally heterogeneous mix of vegetation cover that creates variation in habitat quality, rather than a sharp contrast between habitat patches and the matrix. This heterogeneity arises partly because land-use, ownership and management boundaries often do not correspond to builtinfrastructure boundaries, e.g. multiple domestic gardens, each with their own manager, can form a single patch of green space [90]. Gardens vary greatly in management and resource provision [100], driven by variation in their size and age [101], local laws, social norms and the preferences and interests of those who manage them [102-104]. The cumulative effects of many small-scale management decisions by multiple land owners is a key difference between urban and non-urban regions in determining the spatial scale of heterogeneity. Understanding species responses to this environment is one challenge, but it also poses a major issue in urban conservation management (see Urban biodiversity in planning and management). Internal fragmentation of green space also arises from other anthropogenic impacts including the relatively poor habitat quality of mown amenity grassland that creates dispersal barriers for many species [105, 106], creation of paths [63], trampling [107] and rubbish dumping [108], as well as environmental pollutants including light [109] and noise [110].
How organisms disperse through and use this complex mosaic of resources is not well understood $[111 \bullet, 112]$. To understand how organisms use urban environments, there is a need to move towards an organism-focused definition of landscapes $[75,113]$, and to develop a more detailed understanding of how different organisms use what has typically been perceived to be a hostile urban matrix $[67,114]$. Although not directly addressing the issue of species diversity, an organism-focused approach can contribute to a mechanistic understanding of urban community composition and may provide important insights into the sustainability of those communities into the future. Species' responses to urban landscape structure will depend on the scale at which they respond to the landscape $[66,69,115$, 116], the extent to which particular landscape elements act as barriers and whether their resource requirements are met in the urban environment $[76,117]$. Species that have high daily movement or seasonal dispersal requirements need either to have large areas of continuous green space, or need to be able to integrate multiple small urban fragments into one home range $[115,118,119]$. This can include diverse 'green infrastructure' elements such as corridors, street trees and small parks [94, 120, 121]. Different species will have different capacities to functionally connect patches that are frequently structurally disconnected by impervious surface cover [119, 122]. Generalist mammals, for example the European badger (Meles meles) and hedgehog (Erinaceus europaeus), can use diverse urban green spaces to forage, but require higher-quality habitat for sleeping [111 123], and change their movement patterns when moving through open grassed areas or across roads [123]. Species requiring large, relatively undisturbed areas of continuous forest do not typically tolerate fragmented urban habitats very well $[61 \bullet, 64,124,125]$, but even some specialists will use areas traditionally perceived by researchers as unsuitable, or matrix, habitat, to forage [126], or they will use a network of patches with specialist resources interspersed by less desirable areas as a home range [118]. Species considered generalists tend to dominate as the extent of grey cover increases in cities [28, 63, 127] and this is likely because they can more readily make use of an intensely urbanised environment $[68,128]$ and move between spatially isolated resources.

Species with low mobility may be able to persist in small, fragmented patches [116, 129], provided that they can tolerate the conditions. Species with low mobility, particularly those with specialist habitat requirements, are more likely to be vulnerable to processes such as direct habitat loss or reduction in habitat quality, than to the urban environment as a filter [130]. Despite this, limited innate dispersal ability is sometimes overcome in cities through transport by humans, either deliberate, for example through trade in cultivated plants [131], or accidental, by transport on cars [132] or movement of soil [133]. The extent to which this is important in structuring populations and community composition is not well understood (but see [134]). 


\section{Temporal Dynamics}

Time is an important component of landscape ecology, but has been given rather little attention in urban ecology [84]. Urban systems are intensely managed but this can have opposing impacts on their dynamism. On the one hand, notable creation and loss of urban green space can occur within a decade, and is frequently driven by changes in planning policy $[19,135$, 136]. The rate of temporal dynamics appears to be negatively correlated with green space area, so that smaller areas exhibit more rapid turnover [137, 138], although long-term studies have been limited by the lack of sufficiently high-resolution data [86]. Small areas of green can be subject to changes in policy, but are more vulnerable to decisions made by private land holders ([138], Urban biodiversity in planning and management), the results of which may only be detected a number of years after they are made [139].

Rapid change in urban landscapes through human decision making, e.g. removal of buildings through development programmes, can create sites dominated by earlysuccessional communities that are often commoner in urban than rural areas and provide important habitats for threatened species [132]. These brownfield sites are, however, often short-lived due to pressure to accommodate increasing human populations and policies that promote development of these sites [140]. Urban systems can also have lower rates of some types of disturbance compared to rural areas. For example, regular burning of fire-dependent vegetation communities is not always possible in densely populated areas [141-143] and fire suppression can lead to increased vegetation cover and changed species composition [132, 143]. Conversely, the intense management of urban habitats through activities such as mowing and pruning can lead to large areas in which frequent disturbances limit the rate of vegetation succession creating non-dynamic urban systems [144], for example lawn and mown amenity grassland, and leading to the loss of important resources such as old, hollow-bearing trees [145].

Seasonal dynamics also vary between urban and rural areas, but here the influence of urbanisation is typically to reduce dynamics. Urban heat island effects can increase the length of the growing season, leading to changed plant phenology [146], and may reduce migratory behaviour in urban bird populations [147]. Vegetation growing seasons and phenology can also be extended by irrigation in arid areas [127] or planting non-native ornamental plants that extend the flowering season [148-150]. Finally, deliberate resource supplementation (e.g. feeding garden birds [151]) or accidental supplementation (e.g. increased access to garbage [152]) can reduce the seasonal fluctuation in food availability typical of non-urban environments.

The consequences for biodiversity of the temporal dynamics characteristic of urban landscapes are poorly understood, certainly when compared with the spatial patterns described earlier. Reduction in seasonal dynamics through resource supplementation at garden bird feeders is one aspect that is comparatively well studied. Resource supplementation has been associated with changed bird species composition [153], altered migration patterns [154] and altered productivity rates $[151,155]$. Rapid turnover of urban green space and changes in its composition over longer time scales are likely to promote some form of metapopulation-like structure, with species distributions constantly changing as species-defined patches improve or decline in utility in something probably most closely analogous to the 'species sorting' model [156]. Many species are thus likely to only be present in a proportion of suitable areas at any one time. Rapid switching of patches from suitable to unsuitable habitat may increase local extinction rates to a point that species with insufficiently high dispersal rates will decline to extinction across the whole mosaic. Reducing the risk of such extinctions requires sensitive landscape-scale management of habitats and connecting land [157].

\section{Alternative Models for a Heterogeneous Urban Landscape}

The spatially-heterogeneous and temporally-dynamic urban environment can only be incompletely understood using a binary patch-matrix conception of the landscape [158]. The hierarchical patch dynamic paradigm conceptualises the urban environment as hierarchically nested spatial units that are temporally dynamic and defined depending on the study system and scale [159]. This approach has been widely acknowledged as potentially useful in conceptualising urban environments [84, 160-163]. It has been successfully used to capture spatial heterogeneity in habitat quality of urban landscapes [83, 98, 164], to develop research frameworks to understand the human socio-economic drivers of these patterns [161] and to evaluate some urban ecosystem processes [165]. Hierarchical patch dynamic models also have the capacity to incorporate temporal change, although such uses are rare [84]. Wider adoption of this framework for research has potential for a detailed understanding of urban systems, but its complexity has restricted uptake of the method, and may limit wide implementation.

An additional challenge to developing models for biodiversity responses to heterogeneous urban landscapes, albeit one not limited to urban systems, is how to incorporate the divergent responses of multiple species, when moving from a patch- to an organism-centred approach. Methods for applying an organism-centred approach include graph theory [118, 166, 167] and species distribution and habitat models (e.g. [113]), which have allowed researchers to explore responses of particular species, or functionally similar groups of species, to both spatially and temporally dynamic patches (e.g. [137]) and can be applied at multiple scales $[168,169]$. While there is 
much to recommend an organism-centred approach, a key limitation is that it is not possible to model the response of all organisms. In conservation practice, solutions have been tested where 'representative focal' species, 'umbrella' species, or groups of species linked by shared ecological traits are targeted for planning assuming the needs of other organisms will also be met by those. The effectiveness of this approach has, however, been queried (e.g. [170-172]). Applying these different and complex models is becoming more tractable with the increasing availability of high-resolution maps that better capture the heterogeneity of urban landscapes [83] at appropriate scales for a range of very different organisms $[86,99$, $113]$.

\section{Urban Biodiversity in Planning and Management}

Urban biodiversity is a broad, complex and scale-dependent concept [162], and this makes it extremely challenging for planners and land managers to take account of it at the level of detail of many of the ecological investigations considered in the preceding sections. Vos et al. [173] argue, drawing on the implementation of ecological corridors in the Netherlands, that developing workflows to transfer ecological understanding of biodiversity into spatial planning involves three stages: the analysis of species' ecological characteristics in relation to the type and scale of spatial problem being addressed, synthesis of that knowledge to provide robust generalisations relevant to the full range of relevant species, and use of these generalisations to produce flexible design rules that can be applied in the complexity of the real world. As the previous sections have outlined, knowledge about the response of biodiversity to the characteristics of urban landscapes is developing rapidly, in some areas starting to allow broader generalisations to be tested using compilations of multiple case studies, particularly at the within-city, rather than city-level, scale. However, there is also still much that is speculative, or known only from a few specific studies.

Despite these knowledge gaps and uncertainties, planners need principles with which to work [174]. This need for principles to guide urban management is met by numerous planning guidelines and documents (for example in the UK: [175-181]). These documents largely draw on the basic tenets of patch-matrix landscape ecology [182-185], primarily those concerned with patch size, connectivity and, to a slightly lesser extent, disturbance, and reinforce these using case studies and examples from urban planning. In some areas the need for advice may have outpaced the scientific evidence [120], although the general principles "more, bigger, better and joined" [186] for conservation of any habitat are likely to be good, and precautionary [187], guidance.

However, most of these guidelines discuss actual biodiversity rather little, but are framed in terms of 'green space' or, increasingly, 'green infrastructure' (GI). Green infrastructure is a multifaceted, even contested [188], term but one which provides a nexus between disciplines, bringing green space into the same framework as other planning concepts, being applicable at a range of scales, emphasising multifunctionality and creation as well as preservation [189-194]. Elements of GI such as 'greenways' [194, 195] are widely recommended and adopted but biodiversity conservation is not usually the primary driver for their creation [189, 190, $195,196]$. This, in turn, leads to the more general issue that biodiversity is only one of several strands to the rationale for promoting green space in urban systems, and increasingly GI is promoted as part of the broader sustainability agenda, using the currency of ecosystem services and emphasising the concept of resilience $[187,190]$. Biodiversity is often neglected in such discussions [190, 197], and management goals for restoration or enhancement of ecosystem services do not necessarily align well with those for biodiversity [198]. This neglect is compounded by the variety of goals that 'enhancing biodiversity' can entail, from general increases in species richness to increased occurrence or abundance of certain species. Even where biodiversity is a goal, if the term is not well defined then the success of the project is difficult to measure. While guidance documents (e.g. see list above) provide diverse and creative ways to enhance GI provision, they often make the tacit assumption that biodiversity improvement will follow. This shared agenda suggests that two key roles for urban biodiversity research to support urban planning are: (i) testing how biodiversity responds to different GI elements (see Within-city biodiversity); and (ii) understanding how biodiversity relates to the ecosystem services GI is created to support.

At a more conceptual level, it is also important to recognise that ideas and theoretical frameworks in urban planning (see for example the discourse over New Urbanism and Landscape Urbanism [199-201]) are espousing the GI and sustainability agendas and make many assumptions about ecological processes, but are developed and debated outside the ecological literature. There is clearly scope for more engagement between natural science and planning in these discussions [202]. While, arguably, planners could make more use of ecological science, equally, in the interests of both saliency, legitimacy, and therefore uptake, of knowledge [203, 204], it is also incumbent on ecologists to consider such planning models and theories as frameworks for biodiversity research, both in terms of testing the propositions, and in terms of mapping across ideas from such models to existing concepts in ecology (e.g. see discussion of land-sharing/sparing below).

Different elements of planning frameworks and legislation operate at different scales $[205,206]$. One key issue that arises from this is that there may be scale mismatches between planning or management and the ecological systems and processes affected, and that the fine-scale heterogeneity of urban systems may make this particularly acute $[183,206,207 \cdot, 208$, 
209]. This leads to the argument that management should take a more holistic integrated view of the urban landscape as a dynamic, complex landscape with multiple elements of both built, and green, space and the links between them [207•]. This echoes the importance of the combined small-scale mo-saic of green and non-green space for many organisms (see Within-city biodiversity), and also the caution that approaches that overemphasise the protection of high quality green spaces may inadvertently lead to neglect of other important features [210]. For example, wasteground (i.e. brownfield sites) may have an important role in supporting biodiversity, but this value may not be recognised in green space planning ([89, 137, 211•] also see Within-city biodiversity). The issue of links and interactions among patches points to another planning issue which is the influence of adjacent areas on the value ]and role of individual patches of green space, requiring understanding, planning and subsequent maintenance of complementary land-use configurations $[212,213]$. The importance of the combination of multiple small elements of green space also emphasises the significance of small-scale (e.g. landparcel level) planning decisions, and subdivision of land among multiple owners - e.g. householders (see Within-city biodiversity). This is illustrated by the change (generally loss) of urban green space over time by multiple small changes such as infill development, paving front yards and increased building footprints with successive redevelopments [135, 183, 214-216], and the responsiveness of this to planning policy [135].

At larger (typically regional and sub-regional) scales, the role of landscape planning is more clearly evident, where major types of urban development are typically classes of landuse along with other non-urban designations, suggesting that some of the issues considered at the city scale (see City-level biodiversity) may be of relevance here. At these scales, various tools and data acquisition and management systems are being developed, or adapted, for use in urban regions. Examples include: integration of data across multiple different sources and agencies [217, 218], development of indicator indices for practical assessment of diversity [219], improving data resolution to capture more effectively the spatial scale and heterogeneity of land-use [83, 220], modelling fine-scale connectivity [221], development of indicators and analytical methods for prioritisation of areas for conservation or development [222, 223], exploration of different urban growth scenarios [224], optimisation of overall land-use mixes (including urban land) for biodiversity value [225], and use of highthroughput computing to improve the tractability of such demanding analytical tasks [226]. Many of these approaches are aimed at identifying areas for new urban development, but they could potentially be adapted to account for smallerscale heterogeneity within sections of new or existing urban development. This approach would generate new demands on data quantity, resolution and classifications, and might require alteration of approaches that work for large land parcels as some biological processes, and their representation in such models (e.g. indices of integrity, habitat suitability for a species, metapopulation processes), will not necessarily translate to a finer-grained green-space mosaic, which is emerging as a key characteristic of urban systems (see Within-city biodiversity).

Underpinning such allocation and optimisation approaches is the need to understand the trade-offs, in terms of environmental impacts, among different locations, sizes and spatial structures of urban development. Such trade-offs may be at the scale of the whole city in its regional context or within urban areas, where configuration of the built areas may be highdensity aggregations ("land sparing"), or much more uniformly dispersed ("land sharing") [23]. Taken simply, and at the whole-city scale, the land-sparing approach has all development concentrated in a small but densely populated urban area, with limited internal green space, but leaving as much of the surrounding area undeveloped as possible [23]. The value of this sparing for biodiversity may depend on the habitat quality and other uses made of the spared land, and the nature of any green space retained in the urban area. Landsharing approaches, by contrast, are typically seen as lower density development with relatively uniform dispersion of buildings and infrastructure, thus creating a larger urban area with lower human population density and, potentially, more internal green space. These considerations also apply at smaller spatial scales than the entire urban area, for example individual housing developments. Initial analyses of such scenarios suggest the potential for negative effects of land sharing on diversity, abundance and particularly on species that are poorly adapted to urban environments [124, 227, 228•]. It is important, however, to go beyond the use of simple overall density of the urban area as a metric and consider the spatial configuration of urban development within the urban boundary [23, 228.]. The predicted effects of urban intensity on biodiversity depend on the particular responses of each species to intensity of urban development, and whether aggregated or dispersed development is predicted to be better may depend on the overall intensity of urbanisation [227]. There is some evidence that urban developments that aggregate housing with tracts of green space between clustered buildings, e.g. 'conservation subdivision' [229], can be better for biodiversity than developments that have the same overall housing density in a more spatially uniform development [230], but achieving these benefits still requires attention to small-scale details of management and planning (such as access regimes and planting schemes) [214] and needs detailed ecological and design guidance [231]. A more complete understanding of the relative merits for biodiversity conservation of alternative approaches to meeting the increasing demand for urban land requires a more complete understanding of how urban intensity, city size and the spatial configuration of urban and non-urban areas 
interact to determine biodiversity ([23], see also City-level biodiversity). There remains much more to be done to establish the best way to develop cities for biodiversity, but Sushinsky et al.'s [228•] spatially explicit modelling approach suggests how we might move beyond the general to explore more specific development scenarios. Interestingly, there are echoes of this debate in the discussions about New Urbanism and Landscape Urbanism referred to earlier, though these are apparently unacknowledged in either the ecological or planning literature.

Planning is the process of reaching an implementable decision through balancing social, environmental, technical and design considerations, within a particular legislative framework in which scientists participate as one of a number of stakeholders: "Planning is not science. Planning is action." [232]. Analyses of planners' use of biodiversity concepts and information [233-235] suggest that biodiversity considerations play a limited role in urban planning relative to planning directives and the human health and recreation agendas. One issue here is the availability of specific guidance, tools and workflows that are tractable and effective for planners to use. Landscape ecology and biodiversity science have a key role to play here in translating sometimes complex, contingent and data-demanding scientific results into practical and effective workflows $[173,236 \cdot, 237]$. Better integration of landscape ecology and biodiversity research into planning is clearly possible, and recent developments are encouraging. Nonetheless, biodiversity will remain just one strand of the planning process and ensuring its effective incorporation into urban development, or redevelopment, will remain a challenge. Key to this is recognizing that urban development is a process of doing large-scale 'experiments' with the landscape $[190,238,239]$ and landscape ecology provides a set of hypotheses about the ecological outcomes of this variation [173] (many of which are discussed in the earlier sections). These situations provide opportunities for learning processes to be embedded in the relevant socio-ecological setting, through in situ experimental manipulations [240], or by using the design process to provide the ground for knowledge transfer in both directions between science and practice [239]. Biodiversityled landscape ecology needs to be setting challenging and relevant hypotheses, fully engaged with assessing the outcomes and committed to making this knowledge operational, if it is to be an influential stakeholder in the urban planning process.

\section{Conclusion}

Effective planning for biodiversity in cities and towns is increasingly important as urban areas and their human populations grow, both to achieve conservation goals and because ecological communities support ecosystem functions and services on which humans depend. Landscape ecology has played an important role in the development of a substantial, and rapidly expanding, body of knowledge about urban landscapes and communities. Most of this research has focused within cities but, increasingly, interest in cross-city comparisons is also starting to provide important insights into urban biodiversity patterns. There is considerable potential for incorporation of such information into regional-level planning, particularly in considering the relationships among different characteristics of urban systems, such as those between the size of an urban area and the amount of green space that it contains, and how these vary depending on a city's context. Such approaches will provide a more nuanced picture of how contrasting urbanisation patterns would influence regional biodiversity. Within cities, although there is still much emphasis on the patch-matrix concepts of urban green space, useful progress has been made in better characterising spatial heterogeneity at multiple scales and incorporating this into biodiversity research, while the effects of temporal dynamics in urban green space must clearly be a future research priority. An additional area for future work is in consideration of interactions between city-level and within-city characteristics, for example whether city size determines the influence of connectivity between urban green spaces on local biodiversity. Incorporation of the recent advances in understanding urban biodiversity into planning depends substantially on ecologists participating in the development of tools, workflows that distil the science into flexible, manageable rules and practical procedures as well as engaging in research that is more participatory in the design process. Our understanding of the processes that determine urban biodiversity is increasing rapidly, but so is urbanisation, and keeping up is not a trivial challenge.

Acknowledgments This research (Grant Number NE/J015369/1) was conducted as part of the Fragments, Functions and Flows in Urban Ecosystem Services $\left(\mathrm{F}^{3} \mathrm{UES}\right)$ Project as part of the larger Biodiversity and Ecosystem Service Sustainability (BESS) framework. BESS is a six-year programme (2011-2017) funded by the UK Natural Environment Research Council (NERC) and the Biotechnology and Biological Sciences Research Council (BBSRC) as part of the UK's Living with Environmental Change (LWEC) programme. The views expressed are those of the authors and not necessarily those of the BESS Directorate or NERC. We are grateful to Gavin Siriwardena and an anonymous referee for helpful comments on the manuscript.

\section{Compliance with Ethical Standards}

Conflict of Interest On behalf of all authors, the corresponding author states that there is no conflict of interest.

Human and Animal Rights and Informed Consent This article contains no studies with human or animal subjects performed by the authors.

Open Access This article is distributed under the terms of the Creative Commons Attribution 4.0 International License (http:// 
creativecommons.org/licenses/by/4.0/), which permits unrestricted use, distribution, and reproduction in any medium, provided you give appropriate credit to the original author(s) and the source, provide a link to the Creative Commons license, and indicate if changes were made.

\section{References}

Papers of particular interest, published recently, have been highlighted as:

- Of importance

1. Wu J. Urban ecology and sustainability: the state-of-the-science and future directions. Landsc Urban Plan. 2014;125:209-21.

2. Niemelä J. Ecology of urban green spaces: the way forward in answering major research questions. Landsc Urban Plan. 2014; 125:298-303.

3. Fragkias M, Güneralp B, Seto KC, Goodness J. A synthesis of global urbanization projections. In: Elmqvist T, Fragkias M, Goodness J, Güneralp B, Marcotullio PJ, McDonald RI, et al., editors. Urbanization, biodiversity and ecosystem services: challenges and opportunities, A global assessment. London: Springer; 2013. p. 1-12.

4. Soga M, Gaston KJ. Extinction of experience: the loss of humannature interactions. Front Ecol Environ. 2016;14:94-101.

5. Seto KC, Güneralp B, Hutyra LR. Global forecasts of urban expansion to 2030 and direct impacts on biodiversity and carbon pools. Proc Natl Acad Sci U S A. 2012;109:16083-8.

6. Ives CD, Lentini PE, Threlfall CG, et al. Cities are hotspots for threatened species. Global Ecol Biogeogr. 2016;25:117-26.

7. Grimm NB, Faeth SH, Golubiewski NE, et al. Global change and the ecology of cities. Science. 2008;319:756-60.

8. Seto KC, Reenberg A, Boone CG, et al. Urban land teleconnections and sustainability. Proc Natl Acad Sci U S A. 2012;109:7687-92.

9. Ziter C. The biodiversity-ecosystem service relationship in urban areas: a quantitative review. Oikos. 2016;125:761-8.

10. Dearborn DC, Kark S. Motivations for Conserving Urban Biodiversity. Conserv Biol. 2010;24:432-40.

11. Elmqvist T, Fragkias M, Goodness J, et al., editors. Urbanization, biodiversity and ecosystem services: challenges and opportunities: a global assessment. London: Springer; 2013.

12. Nelson E, Mendoza G, Regetz J, et al. Modeling multiple ecosystem services, biodiversity conservation, commodity production, and tradeoffs at landscape scales. Front Ecol Environ. 2009;7:411.

13. Wu J. Key concepts and research topics in landscape ecology revisited: 30 years after the Allerton Park workshop. Landscape Ecol. 2013;28:1-11.

14. Müller N, Kamada M. URBIO: an introduction to the International Network in Urban Biodiversity and Design. Landsc Ecol Eng. 2011;7:1-8.

15. McKinney ML. Urbanization as a major cause of biotic homogenization. Biol Conserv. 2006;127:247-60.

16. Evans KL, Hatchwell BJ, Parnell M, Gaston KJ. A conceptual framework for the colonisation of urban areas: the blackbird Turdus merula as a case study. Biol Rev. 2010;85:643-67.

17. La Sorte FA, Aronson MFJ, Williams NSG, et al. Beta diversity of urban floras among European and non-European cities. Global Ecol Biogeogr. 2014;23:769-79.
18. Dobbs C, Nitschke CR, Kendal D. Global drivers and tradeoffs of three urban vegetation ecosystem services. PLoS One. 2014;9: e113000.

19. Yang J, Huang C, Zhang Z, Wang L. The temporal trend of urban green coverage in major Chinese cities between 1990 and 2010. Urban For Urban Gree. 2014;13:19-27.

20. Fuller RA, Gaston KJ. The scaling of green space coverage in European cities. Biol Lett. 2009;5:352-5.

21. Aronson MFJ, La Sorte FA, Nilon CH, et al. A global analysis of the impacts of urbanization on bird and plant diversity reveals key anthropogenic drivers. P Roy Soc B-Biol Sci. 2014;281: 20133330. This paper provides an excellent example of how data are now being brought together from many cities to examine how city-level traits relate to urban biodiversity. It is the largest global dataset of its type up to 2014 and covers both plants and birds.

22. Bettencourt LMA. The origins of scaling in cities. Science. 2013;340:1438-41.

23. Lin BB, Fuller RA, Thompson D. Sharing or sparing? How should we grow the world's cities? J Appl Ecol. 2013;50:1161-8.

24. Pautasso M, Böhning-Gaese K, Clergeau P, et al. Global macroecology of bird assemblages in urbanized and seminatural ecosystems. Global Ecol Biogeogr. 2011;20:426-36.

25. Evans KL, Newson SE, Gaston KJ. Habitat influences on urban avian assemblages. Ibis. 2009;151:19-39.

26. Ferenc M, Sedláček O, Fuchs R, Dinetti M, Fraissinet M, Storch D. Are cities different? Patterns of species richness and beta diversity of urban bird communities and regional species assemblages in Europe. Global Ecol Biogeogr. 2014;23:479-89. The paper compares scaling relationships between urban and rural areas and provides a valuable contribution to a small literature on the influence of city size on urban biodiversity.

27. Forister ML, Novotny V, Panorska AK, et al. The global distribution of diet breadth in insect herbivores. Proc Natl Acad Sci U S A. 2015;112:442-7.

28. Evans KL, Chamberlain DE, Hatchwell BJ, Gregory RD, Gaston KJ. What makes an urban bird? Glob Change Biol. 2011;17:32 44.

29. Faeth SH, Bang C, Saari S. Urban biodiversity: patterns and mechanisms. Ann NY Acad Sci. 2011;1223:69-81.

30. Ward P. Origin of the avifauna of urban and suburban Singapore. Ibis. 1968;110:239-55.

31. Cook WM, Faeth SH. Irrigation and land-use drive ground arthropod community patterns in an urban desert. Environ Entomol. 2006;35:1532-40.

32. Ackley JW, Angilletta JM, DeNardo D, Sullivan B, Wu J. Urban heat island mitigation strategies and lizard thermal ecology: landscaping can quadruple potential activity time in an arid city. Urban Ecosyst. 2015;18:1447-59.

33. Hui C, Roura-Pascual N, Brotons L, Robinson RA, Evans KL. Flexible dispersal strategies in native and non-native ranges: environmental quality and the 'good-stay, bad-disperse' rule. Ecography. 2012;35:1024-32.

34. Rutz C. The establishment of an urban bird population. J Anim Ecol. 2008;77:1008-19.

35. Cannon AR, Chamberlain DE, Toms MP, Hatchwell BJ, Gaston KJ. Trends in the use of private gardens by wild birds in Great Britain 1995-2002. J Appl Ecol. 2005;42:659-71.

36. Tan M, Li X. Quantifying the effects of settlement size on urban heat islands in fairly uniform geographic areas. Habitat Int. 2015;49:100-6.

37. Schmid PE, Niyogi D. Impact of city size on precipitationmodifying potential. Geophys Res Lett. 2013;40:5263-7.

38. Han L, Zhou W, Pickett STA, Li W, Li L. An optimum city size? The scaling relationship for urban population and fine particulate (PM2.5) concentration. Environ Pollut. 2016;208(Part A):96-101. 
39. Marshall J, Sander H, Manson S. Air pollution and urban form: evidence from satellite data. In: Otesteanu M, Celikyay S, Mastorakis N, Lache S, Benra F, editors. 5th WSEAS International Conference on Environment, Ecosystem and Development; December 14-16, 2007; Tenerife, Spain. Bulgaria: WSEAS Press; 2007. p. 477-9.

40. Czarnecka J, Kitowski I, Sugier P, Mirski P, Krupiński D, Pitucha G. Seed dispersal in urban green space - does the rook Corvus frugilegus L. contribute to urban flora homogenization? Urban For Urban Gree. 2013;12:359-66. This is a rare example of a study that demonstrates how city-level traits (here, city size) influence connectivity between urban and rural areas, in a manner that cascades across trophic levels. It also provides good evidence for an indirect mechanism through which urban plant communities respond to human activities.

41. Kupfer JA. Landscape ecology and biogeography: rethinking landscape metrics in a post-FRAGSTATS landscape. Prog Phys Geog. 2012;36:400-20.

42. Gilchrist A, Barker A, Handley JF. Pathways through the landscape in a changing climate: the role of landscape structure in facilitating species range expansion through an urbanised region. Landsce Res. 2016;41:26-44.

43. Arrhenius O. Species and Area J Ecol. 1921;9:95-9.

44. Martinson HM, Raupp MJ. A meta-analysis of the effects of urbanization on ground beetle communities. Ecosphere. 2013;4:124.

45. Pyšek P. Alien and native species in Central European urban floras: a quantitative comparison. J Biogeogr. 1998;25:155-63.

46. Evans KL, Lennon JJ, Gaston KJ. Slopes of avian species-area relationships, human population density, and environmental. Avian Conserv Ecol. 2007;2:7. [online] URL: http://www.aceeco.org/vol2/iss/art7/.

47. Triantis KA, Mylonas M, Lika K, Vardinoyannis K. A model for the species-area-habitat relationship. J Biogeogr. 2003;30:19-27.

48. MacGregor-Fors I, Morales-Pérez L, Schondube JE. Does size really matter? Species-area relationships in human settlements. Divers Distrib. 2011;17:112-21.

49. Hahs AK, McDonnell MJ. Extinction debt of cities and ways to minimise their realisation: a focus on Melbourne. Ecol Manage Restor. 2014;15:102-10.

50. Soga M, Koike S. Mapping the potential extinction debt of butterflies in a modern city: implications for conservation priorities in urban landscapes. Anim Conserv. 2013;16:1-11.

51. Hahs AK, McDonnell MJ, McCarthy MA, et al. A global synthesis of plant extinction rates in urban areas. Ecol Lett. 2009;12: 1165-73.

52. Brown PH, Miller DM, Brewster CC, Fell RD. Biodiversity of ant species along a disturbance gradient in residential environments of Puerto Rico. Urban Ecosyst. 2013;16:175-92.

53. Madre F, Vergnes A, Machon N, Clergeau P. Green roofs as habitats for wild plant species in urban landscapes: first insights from a large-scale sampling. Landsc Urban Plan. 2014;122:100-7.

54. Evans KL, Gaston KJ, Frantz AC, Simeoni M, Sharp SP, McGowan A et al. Independent colonization of multiple urban centres by a formerly forest specialist bird species. P Roy Soc B-Biol Sci. 2009:rspb-2008,

55. Tait CJ, Daniels CB, Hill RS. Changes in species assemblages within the Adelaide metropolitan area, Australia, 1836-2002. Ecol Appl. 2005;15:346-59.

56. McDonnell M, Hahs A. The future of urban biodiversity research: moving beyond the 'low-hanging fruit'. Urban Ecosyst. 2013;16: 397-409.

57. McDonnell MJ, Hahs AK. The use of gradient analysis studies in advancing our understanding of the ecology of urbanizing landscapes: current status and future directions. Landsc Ecol. 2008;23: $1143-55$.
58. Niemelä J, Kotze DJ. Carabid beetle assemblages along urban to rural gradients: a review. Landsc Urban Plan. 2009;92:65-71.

59. Hahs AK, McDonnell MJ. Selecting independent measures to quantify Melbourne's urban-rural gradient. Landsc Urban Plan. 2006;78:435-48.

60. Conole LE, Kirkpatrick JB. Functional and spatial differentiation of urban bird assemblages at the landscape scale. Landsc Urban Plan. 2011;100:11-23.

61. Beninde J, Veith M, Hochkirch A. Biodiversity in cities needs space: a meta-analysis of factors determining intra-urban biodiversity variation. Ecol Lett. 2015;18:581-92. The first global metaanalysis of the relative importance of local and landscape features influencing biodiversity within cities.

62. Farinha-Marques P, Lameiras JM, Fernandes C, Silva S, Guilherme F. Urban biodiversity: a review of current concepts and contributions to multidisciplinary approaches. CIEJ. 2011;24:247-71.

63. Jones E, Leather S. Invertebrates in urban areas: a review. Eur J Entomol. 2012;109:463-78.

64. Soga M, Kanno N, Yamaura Y, Koike S. Patch size determines the strength of edge effects on carabid beetle assemblages in urban remnant forests. J Insect Conserv. 2013;17:421-8.

65. Garden J, McAlpine C, Peterson ANN, Jones D, Possingham H. Review of the ecology of Australian urban fauna: a focus on spatially explicit processes. Austral Ecol. 2006;31:126-48.

66. Lizee M-H, Manel S, Mauffrey J-F, Tatoni T, Deschamps-Cottin M. Matrix configuration and patch isolation influences override the species-area relationship for urban butterfly communities. Landsc Ecol. 2012;27:159-69.

67. Matteson KC, Grace JB, Minor ES. Direct and indirect effects of land-use on floral resources and flower-visiting insects across an urban landscape. Oikos. 2013;122:682-94.

68. Pellissier V, Cohen M, Boulay A, Clergeau P. Birds are also sensitive to landscape composition and configuration within the city centre. Landsc Urban Plan. 2012;104:181-8.

69. Pennington DN, Blair RB. Habitat selection of breeding riparian birds in an urban environment: untangling the relative importance of biophysical elements and spatial scale. Divers Distrib. 2011;17: 506-18.

70. McKinney M. Effects of urbanization on species richness: a review of plants and animals. Urban Ecosyst. 2008;11:161-76.

71. Saari S, Richter S, Higgins M, Oberhofer M, Jennings A, Faeth $\mathrm{SH}$. Urbanization is not associated with increased abundance or decreased richness of terrestrial animals - dissecting the literature through meta-analysis. Urban Ecosyst. 2016. doi:10.1007/s11252016-0549-x:1-14.

72. Sol D, Gonzalez-Lagos C, Moreira D, Maspons J, Lapiedra O. Urbanisation tolerance and the loss of avian diversity. Ecol Lett. 2014;17:942-50.

73. MacArthur RH. Geographical ecology: patterns in the distribution of species. Oxford: Princeton University Press; 1972.

74. Fischer J, Lindenmayer DB. Landscape modification and habitat fragmentation: a synthesis. Global Ecol Biogeogr. 2007;16:26580.

75. Kirchhoff T, Trepl L, Vicenzotti V. What is landscape ecology? An analysis and evaluation of six different conceptions. Landsc Res. 2013;38:33-51.

76. Murphy HT, Lovett-Doust J. Context and connectivity in plant metapopulations and landscape mosaics: does the matrix matter? Oikos. 2004;105:3-14.

77. Driscoll DA, Banks SC, Barton PS, Lindenmayer DB, Smith AL. Conceptual domain of the matrix in fragmented landscapes. Trends Ecol Evol. 2013;28:605-13.

78. Haila Y. A conceptual genealogy of fragmentation research: from island biogeography to landscape ecology. Ecol Appl. 2002;12: $321-34$. 
79. Villard M-A, Metzger JP. Beyond the fragmentation debate: a conceptual model to predict when habitat configuration really matters. J Appl Ecol. 2014;51:309-18.

80. Franklin JF, Lindenmayer DB. Importance of matrix habitats in maintaining biological diversity. Proc Natl Acad Sci U S A. 2009;106:349-50.

81. Prugh LR, Hodges KE, Sinclair ARE, Brashares JS. Effect of habitat area and isolation on fragmented animal populations. Proc Natl Acad Sci U S A. 2008;105:20770-5.

82. Watling JI, Nowakowski AJ, Donnelly MA, Orrock JL. Metaanalysis reveals the importance of matrix composition for animals in fragmented habitat. Global Ecol Biogeogr. 2011;20:209-17.

83. Cadenasso ML, Pickett STA, Schwarz K. Spatial heterogeneity in urban ecosystems: reconceptualizing land-cover and a framework for classification. Front Ecol Environ. 2007;5:80-8.

84. Ramalho CE, Hobbs RJ. Time for a change: dynamic urban ecology. Trends Ecol Evol. 2012;27:179-88.

85. Faeth SH, Saari S, Bang C. Urban biodiversity: patterns, processes and implications for conservation. eLS. Chichester: Wiley; 2012.

86. Qian Y, Zhou W, Yu W, Pickett SA. Quantifying spatiotemporal pattern of urban greenspace: new insights from high resolution data. Landsc Ecol. 2015;30:1165-73. This research quantifies temporal patterns of urban green space at multiple scales. It highlights how small but potentially important patches of green space are only detected with high-resolution sensors and that these are temporally unstable habitats.

87. Martin LJ, Blossey B, Ellis E. Mapping where ecologists work: biases in the global distribution of terrestrial ecological observations. Front Ecol Environ. 2012;10:195-201.

88. Nielsen AB, van den Bosch M, Maruthaveeran S, van den Bosch CK. Species richness in urban parks and its drivers: a review of empirical evidence. Urban Ecosyst. 2014;17:305-27.

89. Bonthoux S, Brun M, Di Pietro F, Greulich S, Bouché-Pillon S. How can wastelands promote biodiversity in cities? Review Landsc xUrban Plan. 2014;132:79-88.

90. Goddard MA, Dougill AJ, Benton TG. Scaling up from gardens: biodiversity conservation in urban environments. Trends Ecol Evol. 2010;25:90-8.

91. Morelli F, Beim M, Jerzak L, Jones D, Tryjanowski P. Can roads, railways and related structures have positive effects on birds? - a review. Transport Res D-Tr E. 2014;30:21-31.

92. Rupprecht CDD, Byrne JA, Garden JG, Hero J-M. Informal urban green space: a trilingual systematic review of its role for biodiversity and trends in the literature. Urban For Urban Green. 2015;14: 883-908.

93. Speak AF, Mizgajski A, Borysiak J. Allotment gardens and parks: provision of ecosystem services with an emphasis on biodiversity. Urban For Urban Green. 2015;14:772-81.

94. Ikin K, Knight E, Lindenmayer DB, Fischer J, Manning AD. The influence of native versus exotic streetscape vegetation on the spatial distribution of birds in suburbs and reserves. Divers Distrib. 2013;19:294-306.

95. Jim CY. Ecology and conservation of strangler figs in urban wall habitats. Urban Ecosyst. 2013;17:405-26.

96. Tratalos J, Fuller RA, Warren PH, Davies RG, Gaston KJ. Urban form, biodiversity potential and ecosystem services. Landsc Urban Plan. 2007;83:308-17.

97. Zhou X, Wang Y-C. Spatial-temporal dynamics of urban green space in response to rapid urbanization and greening policies. Landsc Urban Plan. 2011;100:268-77.

98. Dupras J, Marull J, Parcerisas L, et al. The impacts of urban sprawl on ecological connectivity in the Montreal metropolitan region. Environ Sci Policy. 2016;58:61-73.

99. Zhu M, Jiang N, Li J, Xu J, Fan Y. The effects of sensor spatial resolution and changing grain size on fragmentation indices in urban landscape. Int J Remote Sens. 2006;27:4791-805.
100. Loram A, Tratalos J, Warren PH, Gaston KJ. Urban domestic gardens (X): the extent \& structure of the resource in five major cities. Landsc Ecol. 2007;22:601-15.

101. Smith RM, Gaston KJ, Warren PH, Thompson K. Urban domestic gardens (V): relationships between landcover composition, housing and landscape. Landsc Ecol. 2005;20:235-53.

102. Belaire JA, Westphal L, Minor E. Different social drivers, including perceptions of urban wildlife, explain the ecological resources in residential landscapes. Landsc Ecol. 2016;31:401-13.

103. Sisser JM, Nelson KC, Larson KL, Ogden LA, Polsky C, Chowdhury RR. Lawn enforcement: how municipal policies and neighborhood norms influence homeowner residential landscape management. Landsc Urban Plan. 2016;150:16-25.

104. van Heezik YM, Dickinson KJM, Freeman C. Closing the gap: communicating to change gardening practices in support of native biodiversity in urban private gardens. Ecol Soc. 2012;17:34. doi.10.5751/ES-04712-170134.

105. Adams RV, Burg TM. Influence of ecological and geological features on rangewide patterns of genetic structure in a widespread passerine. Heredity. 2015;114:143-54.

106. Rittenhouse TAG, Semlitsch RD. Grasslands as movement barriers for a forest-associated salamander: migration behavior of adult and juvenile salamanders at a distinct habitat edge. Biol Conserv. 2006;131:14-22.

107. Kotze DJ, Lehvävirta S, Koivula M, O’Hara RB, Spence JR. Effects of habitat edges and trampling on the distribution of ground beetles (Coleoptera, Carabidae) in urban forests. J Insect Conserv. 2012;16:883-97.

108. Stenhouse RN. Fragmentation and internal disturbance of native vegetation reserves in the Perth metropolitan area, Western Australia. Landsc Urban Plan. 2004;68:389-401.

109. Hale JD, Fairbrass AJ, Matthews TJ, Davies G, Sadler JP. The ecological impact of city lighting scenarios: exploring gap crossing thresholds for urban bats. Glob Change Biol. 2015;21:246778.

110. Ware HE, McClure CJW, Carlisle JD, Barber JR. A phantom road experiment reveals traffic noise is an invisible source of habitat degradation. Proc Natl Acad Sci U S A. 2015;112:12105-9.

111. Braaker S, Moretti M, Boesch R, Ghazoul J, Obrist MK, Bontadina F. Assessing habitat connectivity for ground-dwelling animals in an urban environment. Ecol Appl. 2014;24:1583-95. This is one of few papers to show detailed movement patterns of a ground-dwelling species through an urban area. The paper outlines a modelling framework that is potentially useful for planners, and supports it with field data.

112. LaPoint S, Balkenhol N, Hale J, Sadler J, van der Ree R. Ecological connectivity research in urban areas. Funct Ecol. 2015;29:868-78.

113. Betts MG, Fahrig L, Hadley AS, et al. A species-centered approach for uncovering generalities in organism responses to habitat loss and fragmentation. Ecography. 2014;37:517-27.

114. Belaire JA, Whelan CJ, Minor ES. Having our yards and sharing them too: the collective effects of yards on native bird species in an urban landscape. Ecol Appl. 2014;24:2132-43.

115. Kotliar NB, Wiens JA. Multiple scales of patchiness and patch structure: a hierarchical framework for the study of heterogeneity. Oikos. 1990;59:253-60.

116. Sattler T, Duelli P, Obrist MK, Arlettaz R, Moretti M. Response of arthropod species richness and functional groups to urban habitat structure and management. Landsc Ecol. 2010;25:941-54.

117. Ricketts TH. The matrix matters: effective isolation in fragmented landscapes. Am Nat. 2001;158:87-99.

118. Andersson E, Bodin Ö. Practical tool for landscape planning? An empirical investigation of network based models of habitat fragmentation. Ecography. 2009;32:123-32. 
119. Hostetler M, Holling CS. Detecting the scales at which birds respond to structure in urban landscapes. Urban Ecosyst. 2000;4:25-54.

120. Douglas I, Sadler JP. Urban wildlife corridors: conduits for movement or linear habitat. In: Douglas I, Goode D, Houck M, Wang R, editors. The Routledge handbook of urban ecology. Oxford: Routledge; 2011. p. 274-88.

121. Ikin K, Beaty RM, Lindenmayer DB, Knight E, Fischer J, Manning AD. Pocket parks in a compact city: how do birds respond to increasing residential density? Landsc Ecol. 2013;28: 45-56.

122. Wiens JA, van Horne B, Noon BR. Integrating landscape structure and scale into natural resource management. In: Liu J, Taylor WW, editors. Integrating landscape ecology into natural resource management. Cambridge Studies in Landscape Ecology. Cambridge: Cambridge University Press; 2002. p. 23-67.

123. Davison J, Huck M, Delahay RJ, Roper TJ. Restricted ranging behaviour in a high-density population of urban badgers. J Zool. 2009;277:45-53.

124. Caryl FM, Lumsden LF, van der Ree R, Wintle BA. Functional responses of insectivorous bats to increasing housing density support 'land-sparing' rather than 'land-sharing' urban growth strategies. J Appl Ecol. 2016;53:191-201.

125. Chace JF, Walsh JJ. Urban effects on native avifauna: a review. Landsc Urban Plan. 2006;74:46-69.

126. Caryl FM, Thomson K, van der Ree R. Permeability of the urban matrix to arboreal gliding mammals: sugar gliders in Melbourne. Australia Austral Ecol. 2013;38:609-16.

127. Shochat E, Warren PS, Faeth SH, McIntyre NE, Hope D. From patterns to emerging processes in mechanistic urban ecology. Trends Ecol Evol. 2006;21:186-91.

128. MacGregor-Fors I, Schondube JE. Gray vs. green urbanization: relative importance of urban features for urban bird communities. Basic Appl Ecol. 2011;12:372-81.

129. Keitt T, Urban DL, Milne BT. Detecting critical scales in fragmented landscapes. Ecol Soc. 1997;

130. Herrmann DL, Pearse IS, Baty JH. Drivers of specialist herbivore diversity across 10 cities. Landsc Urban Plan. 2012;108:123-30.

131. Kendal D, Williams NSG, Williams KJH. A cultivated environment: exploring the global distribution of plants in gardens, parks and streetscapes. Urban Ecosyst. 2012;15:637-52.

132. Zipperer WC. The process of natural succession in urban areas. In: Douglas I, Goode D, Houck M, Wang R, editors. The Routledge handbook of urban ecology. London: Routledge; 2011. p. 187-97.

133. Field SG, Lange M, Schulenburg H, Velavan TP, Michiels NK. Genetic diversity and parasite defense in a fragmented urban metapopulation of earthworms. Anim Conserv. 2007;10:162-75.

134. Sattler T, Borcard D, Arlettaz R, et al. Spider, bee, and bird communities in cities are shaped by environmental control and high stochasticity. Ecology. 2010;91:3343-53.

135. Dallimer M, Tang Z, Bibby PR, Brindley P, Gaston KJ, Davies ZG. Temporal changes in greenspace in a highly urbanized region. Biol Lett. 2011;7:763-6.

136. Kong F, Nakagoshi N. Spatial-temporal gradient analysis of urban green spaces in Jinan. China Landsc Urban Plan. 2006;78:147-64.

137. Kattwinkel M, Strauss B, Biedermann R, Kleyer M. Modelling multi-species response to landscape dynamics: mosaic cycles support urban biodiversity. Landscape Ecol. 2009;24:929-41.

138. Troy A, Grove JM, O’Neil-Dunne JM, Pickett SA, Cadenasso M. Predicting opportunities for greening and patterns of vegetation on private urban lands. Environ Manage. 2007;40:394-412.

139. Luck GW, Smallbone LT, O'Brien R. Socio-economics and vegetation change in urban ecosystems: patterns in space and time. Ecosystems. 2009;12:604-20.
140. Adams D, De Sousa C, Tiesdell S. Brownfield development: a comparison of North American and British approaches. Urban Stud. 2010;47:75-104.

141. Kareiva P, Watts S, McDonald R, Boucher T. Domesticated nature: shaping landscapes and ecosystems for human welfare. Science. 2007;316:1866-9.

142. Stenhouse NR. Local government conservation and management of native vegetation in urban Australia. Environ Manage. 2004;34: 209-22.

143. Williams NSG, Morgan JW, McDonnell MJ, McCarthy MA. Plant traits and local extinctions in natural grasslands along an urbanrural gradient. J Ecol. 2005;93:1203-13.

144. McKinney ML. Urbanization, biodiversity, and conservation. Bioscience. 2002;52:883-90.

145. Le Roux DS, Ikin K, Lindenmayer DB, Manning AD, Gibbons P. The future of large old trees in urban landscapes. PLoS One. 2014;9:e99403.

146. Neil K, Wu J. Effects of urbanization on plant flowering phenology: a review. Urban Ecosyst. 2006;9:243-57.

147. Evans KL, Newton J, Gaston KJ, Sharp SP, McGowan A, Hatchwell BJ. Colonisation of urban environments is associated with reduced migratory behaviour, facilitating divergence from ancestral populations. Oikos. 2012;121:634-40.

148. Anderies JM, Katti M, Shochat E. Living in the city: resource availability, predation, and bird population dynamics in urban areas. J Theor Biol. 2007;247:36-49.

149. Leong M, Ponisio LC, Kremen C, Thorp RW, Roderick GK. Temporal dynamics influenced by global change: bee community phenology in urban, agricultural, and natural landscapes. Glob Change Biol. 2016;22:1046-53.

150. Williams NSG, McDonnell MJ, Phelan GK, Keim LD, Van Der Ree R. Range expansion due to urbanization: increased food resources attract Grey-headed Flying-foxes (Pteropus poliocephalus) to Melbourne. Austral Ecol. 2006;31:190-8.

151. Robb GN, McDonald RA, Chamberlain DE, Bearhop S. Food for thought: supplementary feeding as a driver of ecological change in avian populations. Front Ecol Environ. 2008;6:476-84.

152. Contesse P, Hegglin D, Gloor S, Bontadina F, Deplazes P. The diet of urban foxes (Vulpes vulpes) and the availability of anthropogenic food in the city of Zurich. Switzerland Mamm Biol. 2004;69:81-95.

153. Fuller RA, Warren PH, Armsworth PR, Barbosa O, Gaston KJ. Garden bird feeding predicts the structure of urban avian assemblages. Divers Distrib. 2008;14:131-7.

154. Plummer KE, Siriwardena GM, Conway GJ, Risely K, Toms MP. Is supplementary feeding in gardens a driver of evolutionary change in a migratory bird species? Glob Change Biol. 2015;21: 4353-63.

155. Harrison TJE, Smith JA, Martin GR, et al. Does food supplementation really enhance productivity of breeding birds? Oecologia. 2010;164:311-20.

156. Leibold MA, Holyoak M, Mouquet N, et al. The metacommunity concept: a framework for multi-scale community ecology. Ecol Lett. 2004;7:601-13.

157. Heard GW, Scroggie MP, Malone BS. Classical metapopulation theory as a useful paradigm for the conservation of an endangered amphibian. Biol Conserv. 2012;148:156-66.

158. Cadenasso ML, Pickett ST. Urban principles for ecological landscape design and maintenance: scientific fundamentals. CATE. 2008;1:Art. 4

159. Wu J, Loucks OL. From balance of nature to hierarchical patch dynamics: a paradigm shift in ecology. Q Rev Biol. 1995;70:439 66.

160. Alberti M. The effects of urban patterns on ecosystem function. Int Regional Sci Rev. 2005;28:168-92. 
161. Pickett STA, Cadenasso ML. Advancing urban ecological studies: frameworks, concepts, and results from the Baltimore Ecosystem Study. Austral Ecol. 2006;31:114-25.

162. Savard J-PL, Clergeau P, Mennechez G. Biodiversity concepts and urban ecosystems. Landsc Urban Plan. 2000;48:131-42.

163. Zipperer WC, Wu JG, Pouyat RV, Pickett STA. The application of ecological principles to urban and urbanizing landscapes. Ecol Appl. 2000;10:685-8.

164. Li C, Li J, Wu J. Quantifying the speed, growth modes, and landscape pattern changes of urbanization: a hierarchical patch dynamics approach. Landsc Ecol. 2013;28:1875-88.

165. Zhang C, Wu J, Grimm NB, McHale M, Buyantuyev A. A hierarchical patch mosaic ecosystem model for urban landscapes: model development and evaluation. Ecol Model. 2013;250:81100 .

166. Snep RPH, Wallis De Vries MF, Opdam P. Conservation where people work: a role for business districts and industrial areas in enhancing endangered butterfly populations? Landsc Urban Plan. 2011;103:94-101.

167. Urban D, Keitt T. Landscape connectivity: a graph-theoretic perspective. Ecology. 2001;82:1205-18.

168. McGarigal K, Wan HY, Zeller KA, Timm BC, Cushman SA. Multi-scale habitat selection modeling: a review and outlook. Landsc Ecol. 2016;31:1161-75.

169. Urban DL, Minor ES, Treml EA, Schick RS. Graph models of habitat mosaics. Ecol Lett. 2009;12:260-73.

170. Favreau JM, Drew CA, Hess GR, Rubino MJ, Koch FH, Eschelbach KA. Recommendations for assessing the effectiveness of surrogate species approaches. Biol Conserv. 2006;15: 3949-69.

171. Lindenmayer DB, Manning AD, Smith PL, et al. The focalspecies approach and landscape restoration: a critique. Conserv Biol. 2002;16:338-45.

172. Roberge J-M, Angelstam PER. Usefulness of the umbrella species concept as a conservation tool. Conserv Biol. 2004;18:76-85.

173. Vos CC, Opdam P, Steingröver E, Reijnen R. Transferring ecological knowledge to landscape planning: a design method for robust corridors. In: Wu J, Hobbs RJ, editors. Key topics in landscape ecology. Cambridge Studies in Landscape Ecology. Cambridge: Cambridge University Press; 2007. p. 227-45.

174. Goode D. Biodiversity as a statutory component of urban planning. In: Douglas I, Goode D, Houck M, Wang R, editors. The Routledge handbook of urban ecology. Oxford: Routledge; 2011. p. 621-9.

175. Space CABE. Greenspace strategies: a good practice guide. London: Commission for Architecture and the Built Environment; 2004.

176. CABE Space. Start with the park: creating sustainable urban green spaces in areas of housing growth and renewal. London: Commission for Architecture and the Built Environment 2005. Report No.: 978-1-84633-000-1.

177. Hickling P. Biodiversity and urban design: an architect's guide. Nottinghamshire Wildlife Trust: Nottingham; 2013.

178. Institute L. Green infrastructure: an integrated approach to landuse. Landscape Institute: Landscape Institute position statement. London; 2013

179. TCPA. Biodiversity by design: a guide for sustainable communities. London: Town and Country Planning Association; 2004.

180. TCPA. The essential role of green infrastructure: eco-towns green infrastructure worksheet. Town and Country Planning Association: Advice to promoters and planners. London; 2008.

181. TCPA. Planning for a healthy environment: good practice guidance for green infrastructure and biodiversity. Town and Country Planning Association and The Wildlife Trusts: London and Newark; 2012
182. Breuste J, Niemelä J, Snep RPH. Applying landscape ecological principles in urban environments. Landscape Ecol. 2008;23:1139-42.

183. Miller JR. Conserving biodiversity in metropolitan landscapes: a matter of scale (but which scale?). Landsc J. 2008;27:114-26.

184. Niemelä J. Ecology and urban planning. Biodivers Conserv. 1999;8:119-31.

185. Stuart-Murray J. Making urban ecology a key element in urban developent and planning. In: Douglas I, Goode D, Houck M, Wang R, editors. The Routledge handbook of urban ecology. Oxford: Routledge; 2011. p. 630-5.

186. Lawton JH, Brotherton PNM, Brown VK, Elphick C, Fitter AH, Forshaw J et al. Making space for nature: a review of England's wildlife sites and ecological network: Report to Defra 2010

187. Niemelä J, Saarela S-R, Söderman T, et al. Using the ecosystem services approach for better planning and conservation of urban green spaces: a Finland case study. Biodivers Conserv. 2010;19: 3225-43.

188. Wright H. Understanding green infrastructure: the development of a contested concept in England. Local Environ. 2011;16:1003-19.

189. European Environment Agency. Green infrastructure and territorial cohesion: the concept of green infrastructure and its integration into policies using monitoring systems. Luxembourg: Publications Office of the European Union 2011. Report No.: 978-92-9213$242-2$.

190. Ahern J. Urban landscape sustainability and resilience: the promise and challenges of integrating ecology with urban planning and design. Landsc Ecol. 2013;28:1203-12.

191. Hansen R, Pauleit S. From multifunctionality to multiple ecosystem services? A conceptual framework for multifunctionality in green infrastructure planning for urban areas. AMBIO. 2014;43: 516-29.

192. Lennon M. Green infrastructure and planning policy: a critical assessment. Local Environ. 2015;20:957-80.

193. Sandström UG. Green infrastructure planning in urban Sweden. Plann Pract Res. 2002;17:373-85.

194. Walmsley A. Greenways: multiplying and diversifying in the $21 \mathrm{st}$ century. Landsc Urban Plan. 2006;76:252-90.

195. Bryant MM. Urban landscape conservation and the role of ecological greenways at local and metropolitan scales. Landsc Urban Plan. 2006;76:23-44.

196. Gobster PH, Westphal LM. The human dimensions of urban greenways: planning for recreation and related experiences. Landsc Urban Plan. 2004;68:147-65.

197. Burgin S. What about biodiversity? Redefining urban sustainable management to incorporate endemic fauna with particular reference to Australia. Urban Ecosyst. 2016;19:669-78.

198. Bullock J, Aronson J, Newton A, Pywell RF, Rey-Benayas JM. Restoration of ecosystem services and biodiversity: conflicts and opportunities. Trends Ecol Evol. 2011;26:541-9.

199. Ellis C. Landscape urbanism and new urbanism: a view of the debate. J Urban Des. 2015;20:303-7.

200. Ruggeri D. Not just a park. The inevitability of urban nature in contemporary city design. J Urban Des. 2015;20:318-20.

201. Thompson IH. Ten tenets and six questions for landscape urbanism. Landsc Res. 2012;37:7-26.

202. Steiner F. Landscape ecological urbanism: origins and trajectories. Landsc Urban Plan. 2011;100:333-7.

203. Cash DW, Clark WC, Alcock F, et al. Knowledge systems for sustainable development. Proc Natl Acad Sci U S A. 2003;100: 8086-91.

204. Opdam P. Learning science from practice. Landsc Ecol. 2010;25: 821-3.

205. Maruani T, Amit-Cohen I. Open space planning models: a review of approaches and methods. Landsc Urban Plan. 2007;81:1-13. 
206. Nassauer JI. Landscape as medium and method for synthesis in urban ecological design. Lands Urban Plan. 2012;106:221-9.

207. Bergsten A, Galafassi D, Bodin Ö. The problem of spatial fit in social-ecological systems: detecting mismatches between ecological connectivity and land management in an urban region. Ecol Soc. 2014;19:6. doi:10.5751/ES-06931-190406. An interesting approach using network analysis to compare ecological connectivity among remnant wetlands with collaboration among planners, allowing identification of the mismatches between the spatial patterns and scales of ecological systems and the administration of their management.

208. Borgström ST, Elmqvist T, Angelstam P, Alfsen-Norodom C. Scale mismatches in management of urban landscapes. Ecol Soc. 2006;11:16. [online] URL: http://www.ecologyandsociety. org/vol1/iss2/art/.

209. Cumming GS, Cumming DHM, Redman CL. Scale mismatches in social-ecological systems: causes, consequences, and solutions. Ecol Soc. 2006;11:14. [online] URL: http://www. ecologyandsociety.org/vol1/iss1/art/.

210. Andersson E, Barthel S, Ahrné K. Measuring social-ecological dynamics behind the generation of ecosystem services. Ecol Appl. 2007;17:1267-78.

211. Kattwinkel M, Biedermann R, Kleyer M. Temporary conservation for urban biodiversity. Biol Conserv. 2011;144:2335-43. This paper is one of very few to incorporate a temporal component into spatial conservation planning in urban areas, focussing particularly on brownfields.

212. Colding J. 'Ecological land-use complementation' for building resilience in urban ecosystems. Landsc Urban Plan. 2007;81:4655.

213. Hostetler M, Allen W, Meurk C. Conserving urban biodiversity? Creating green infrastructure is only the first step. Landsc Urban Plan. 2011;100:369-71.

214. Lenth BA, Knight RL, Gilgert WC. Conservation value of clustered housing developments. Conserv Biol. 2006;20:1445-56.

215. Pauleit S, Ennos R, Golding Y. Modeling the environmental impacts of urban land-use and land-cover change - a study in Merseyside. UK Landsc Urban Plan. 2005;71:295-310.

216. Perry T, Nawaz R. An investigation into the extent and impacts of hard surfacing of domestic gardens in an area of Leeds. United Kingdom Landsc Urban Plan. 2008;86:1-13.

217. Underwood JG, Francis J, Gerber LR. Incorporating biodiversity conservation and recreational wildlife values into smart growth land-use planning. Landsc Urban Plan. 2011;100:136-43.

218. Weber T, Sloan A, Wolf J. Maryland's green infrastructure assessment: development of a comprehensive approach to land conservation. Landsc Urban Plan. 2006;77:94-110.

219. Kohsaka R, Pereira HM, Elmqvist T, et al. Indicators for management of urban biodiversity and ecosystem services: city biodiversity index. In: Elmqvist T, Fragkias M, Goodness J, Güneralp B, Marcotullio PJ, McDonald RI, et al., editors. Urbanization, biodiversity and ecosystem services: challenges and opportunities, A global assessment. London: Springer; 2013. p. 699-718.

220. Hand KL, Freeman C, Seddon PJ, Stein A, van Heezik Y. A novel method for fine-scale biodiversity assessment and prediction across diverse urban landscapes reveals social deprivationrelated inequalities in private, not public spaces. Landsc Urban Plan. 2016;151:33-44.

221. Lechner AM, Doerr V, Harris RMB, Doerr E, Lefroy EC. A framework for incorporating fine-scale dispersal behaviour into biodiversity conservation planning. Landsc Urban Plan. 2015;141:11-23.

222. Chrysochoou M, Brown K, Dahal G, et al. A GIS and indexing scheme to screen brownfields for area-wide redevelopment planning. Landsc Urban Plan. 2012;105:187-98.
223. Gordon A, Simondson D, White M, Moilanen A, Bekessy SA. Integrating conservation planning and landuse planning in urban landscapes. Landsc Urban Plan. 2009;91:183-94.

224. Beardsley K, Thorne JH, Roth NE, Gao S, McCoy MC. Assessing the influence of rapid urban growth and regional policies on biological resources. Landsc Urban Plan. 2009;93:172-83.

225. Polasky S, Nelson E, Camm J, et al. Where to put things? Spatial land management to sustain biodiversity and economic returns. Biol Conserv. 2008;141:1505-24.

226. Leonard PB, Baldwin RF, Duffy EB, Lipscomb DJ, Rose AM. High-throughput computing provides substantial time savings for landscape and conservation planning. Landsc Urban Plan. 2014;125:156-65.

227. Soga M, Yamaura Y, Koike S, Gaston KJ. Land sharing vs. land sparing: does the compact city reconcile urban development and biodiversity conservation? J Appl Ecol. 2014;51:1378-86.

228. Sushinsky JR, Rhodes JR, Possingham HP, Gill TK, Fuller RA. How should we grow cities to minimize their biodiversity impacts? Glob Change Biol. 2013;19:401-10. One of the first papers to explore the land sparing/sharing framework for urban landscape-scale biodiversity planning using spatially explicit scenarios. It presents a method for moving beyond general discussions to specific development scenarios.

229. Hostetler M, Drake D. Conservation subdivisions: a wildlife perspective. Landsc Urban Plan. 2009;90:95-101.

230. Milder JC, Lassoie JP, Bedford BL. Conserving biodiversity and ecosystem function through limited development: an empirical evaluation. Conserv Biol. 2008;22:70-9.

231. Reed SE, Hilty JA, Theobald DM. Guidelines and incentives for conservation development in local land-use regulations. Conserv Biol. 2014;28:258-68.

232. Nilsson KL, Florgard C. Ecological and scientific knowledge in urban and land-use planning. In: McDonnell MJ, Hahs AK, Breuste $\mathrm{JH}$, editors. Ecology of cities and towns: a comparative approach. Cambridge: Cambridge University Press; 2009. p. 549 56.

233. Miller JR, Groom M, Hess GR, et al. Biodiversity conservation in local planning. Conserv Biol. 2008;23:53-63.

234. Sandström UG, Angelstam P, Khakee A. Urban comprehensive planning - identifying barriers for the maintenance of functional habitat networks. Landsc Urban Plan. 2006;75:43-57.

235. Stokes DL, Hanson MF, Oaks DD, Straub JE, Ponio AV. Local land-use planning to conserve biodiversity: planners' perspectives on what works. Conserv Biol. 2010;24:450-60.

236. Gagné SA, Eigenbrod F, Bert DG, et al. A simple landscape design framework for biodiversity conservation. Landscape Urban Plan. 2015;136:13-27. This paper presents a novel, practical framework for how to incorporate effective biodiversity conservation into landscape planning. It is a useful advance as it is flexible enough to be used in many different landscapes.

237. Theobald DM, Hobbs NT, Bearly T, Zack JA, Shenk T, Riebsame WE. Incorporating biological information in local land-use decision making: designing a system for conservation planning. Landsc Ecol. 2000;15:35-45.

238. Felson AJ, Pickett ST. Designed experiments: new approaches to studying urban ecosystems. Front Ecol Environ. 2005;3:549-56.

239. Nassauer J, Opdam P. Design in science: extending the landscape ecology paradigm. Landsc Ecol. 2008;23:633-44.

240. Cook WM, Casagrande DG, Hope D, Groffman PM, Collins SL. Learning to roll with the punches: adaptive experimentation in human-dominated systems. Front Ecol Environ. 2004;2:467-74. 